Journal of Teacher Education for Sustainability

vol. 11, no. 1, pp. 75-85, 2009

\title{
PRESCHOOL AND PRIMARY SCHOOL CHILDREN AS LEARNERS IN 2030: VIEWS OF FINNISH STUDENT TEACHERS
}

\author{
Marja Nurmilaakso \\ University of Helsinki, Finland
}

\begin{abstract}
Teachers are key to the future. Because of enormous future changes, teachers need to re-evaluate their thinking. This study focuses on what student teachers think of the future in preschool and primary school of the year 2030. The questionnaire, conducted in October 2007, reached 76 student teachers from the University of Helsinki in Finland. Of these students, 52 were preschool and 24 primary school student teachers. The research questions were: 1) How important is it that children in preschool and primary school in the year 2030 can use language and communication and can work in groups and in the environment? (2) How can preschool and primary school teachers support language learning and communication in the year 2030? (3) How will children in preschool and primary school in the year 2030 take responsibility for their own (child-centred) learning? The results confirm that preschool and primary school student teachers think very traditionally. Many felt that it would be less important for children in 2030 to speak many languages, and student teachers did not consider the use of computers.
\end{abstract}

Key words: future education; preschool education; primary education; student teacher, language learning; multimedia.

Although Finnish students have good results in the reading, mathematics and natural sciences tests of PISA (Välijärvi et al., 2002) we must remember that we can do even better. The years before the school and first years of school largely determine a child's future. For this reason, teachers are key to the future of children and whole society. Ojala, Siekkinen, and Wright (1996) argue that there is a need for evolution of a new pedagogy. In this vein, we should estimate teachers' existing pedagogical skills and values when we study and plan for the future. In this research student teachers describe their own conceptions of what kind of education will exist in the preschool and primary school in a future. 


\section{Importance of curriculum and specific features of preschool in Finland}

In Finnish society, the foundations of education rest on the ideas of welfare, general human rights, equality, social development; the individual abilities and aptitudes are stressed. Education has grown in importance with the development of children's day care. Consequently, early education is high on the social and political agenda. The aim of this education is to develop abilities and to provide tools already for very young ones that they will need in their further life. In recent decades, early education has been considered a part of the system of education and of lifelong learning. There is also a tendency to tie early education more closely to the needs of commerce and industry as well as those of techno-economic development (Niikko, 2004). In Finland preschool is understood as early childhood education for six-year-olds. Preschool is a part of early childhood education. Compulsory education, or primary school, begins at age seven.

According to Finnish researchers Hujala (2002) and Korkeamäki (2006), a curriculum is the most important document for teaching, for it constructs teachers and policymakers' thinking about children, growth, learning and makes pedagogy visible and understandable to others. The curriculum is a document shared between teachers, parents, children, and, according to recent analysis, the society as a whole. All of these groups should consider the process of curriculum development, implementation and assessment, and recognise that learning must be integrated into children's reality, their everyday lives and the society in which they live. An understanding of the nature of the curriculum is necessary because the policy in Finland is that teachers in the field are professionals capable of making judgments and of interpreting and applying the Finnish National Curriculum, the Core Curriculum for Preschool Education (2000), and the Curriculum for Basic Education (2004) in their own schools and at the classroom level. It is the responsibility of teachers to integrate school subjects into cohesive themes, which cannot be a mere collection of activities.

Therefore, in the preschool, the basis for action is the curriculum. The National Board of Education at the preschool level states in the curriculum (Core Curriculum for Preschool Education in Finland, 2000) that preschool education shall create a foundation for acquiring skills. Children will master basic skills, knowledge and capabilities from different areas according to their age and abilities. Learning through play is essential. Pupils will learn to understand the significance of the peer group in learning. Learning will occur through interaction between the learning material, previously formed knowledge structures and thinking. In interactive peer group situations, children will learn together with and from each other by providing the impetus for the development of thinking and imagination of each group member (ibid.).

The curriculum also stipulates that the beginnings of literacy are determined by following actions: children hear and listen, they are heard, are spoken to, people discuss issues with them, and they have to ask questions and receive answers. In such an environment, children will normally develop their vocabulary and literacy. The curriculum also emphasises the planning of a stimulating environment. A stimulating environment will cultivate children's curiosity, interest and motivation to learn, and promote their activity and self-direction. It will support children's diverse growth and learning as well as assessment of their own activities. The stimulating environment will also provide children with opportunities for play, other activities, and peace and quiet. It will also constitute a stimulating linguistic environment and enable the provision of activities to support children's linguistic development (Core Curriculum for Preschool Education in 
Finland, 2000). Many teachers believe the responsibility to teach reading rests with first grade teachers (Core Curriculum for Basic Education, 2004).

Finnish preschool educators also highly value objectives of environmental education. The environment and natural history, which also includes sustainable development, were the most valued objectives after "general objectives" in the research conducted at Helsinki preschools in 2001. Sustainable development within this context means that the children learn to care for their environment and to behave responsibly. There were 554 preschool teachers in the Helsinki area and 411 teachers participated in the survey constructed to evaluate different preschool objectives. The third most valued area of the preschool curriculum was language (Reunamo \& Nurmilaakso, 2006). Also, Hujala (2002) suggests that Finnish people value environmental issues, diversity and languages to be important components of the curriculum at all stages. The topics of early learning (e.g., communication and language), on which Finnish teachers agree, are important in both preschool and primary school programmes.

Although teachers agree that the topics of learning should be the same in both preschool programmes and the first grade of primary school, they implement them differently. In primary schools, the learning demands are targeted at children. In preprimary programmes, however, the objectives of different topics are set not for the children, but for the teachers as they plan their work to support children's activities in their zone of proximal development (Vygotsky, 1978).

Ojala (2004) emphasises that preschool teachers can support children's learning processes through play and imaginative activities, such as drama, fairy tales and stories. Learning should be organised so that children can learn in everyday situations and teaching should take place together with play, because children at play use their existing experience, which develops as they become better acquainted with themselves and their surrounding environment.

\section{Teacher education in Finland}

What will be new roles and responsibilities of teachers in the future? In the 1990's the chief beneficiaries were non-traditional students or those with limited access to regular study programs. One could argue that in the future, all students should benefit from new technologies. Technology uses a form of literacy that is becoming essential for success in the workplace and in the word. Those who have mastered its use will have a lifelong advantage over those have not (Chen \& Chang, 2006).

According to Yoon (2006), student teachers indicate that the goals of teacher education programmes should be to nurture belief systems, ways of teaching, vision, good personality and subject matter knowledge, thereby meeting the demands of society. They imply that educational programmes should provide experience of personality education, progressive ways of thinking, teacher discourse, and in-depth inquiry into subject matters. With regard to the role of teacher preparation for tomorrow's schools, Yoon says that the majority of co-operating teachers, student teachers and professors believe that the teacher's role has changed from that of an authoritative figure conveying knowledge to that of a guide or facilitator. Though, some teachers and student teachers admit that fundamentally the teachers' role has remained unchanged. Co-operating teachers and student teachers felt that recent world events sparked their concern about personality education and student-centred education. Professors recognised that they 
had become interested in reminding students of the importance of a vision for the future, in rediscovering the intrinsic nature of education, and in emphasising fundamental values.

Some ideas about the teachers' new roles may be found in the results of questionnaire carried out in autumn 2004 at the University of Helsinki (Meri, 2004). In this study 1165 student teachers and student trainers answered questions related to the areas of expertise and core competences of future teachers. The questionnaire contained 204 scales of semantic differentials (see Tabachnick \& Fidell, 2001). The results indicated that teachers value such virtues as commitment, reflection, thoughtfulness, diligence, cooperation, fairness, tolerance and creativity more than teaching skills and subject knowledge. According to Barnes (2008), student teachers need practice. Crucial to student teachers' development is the opportunity to be in a "real" teaching environment, one where they can learn and test themselves.

Smith (2007) who explored how new teachers develop their professional identities and knowledge, also emphasises the importance of experiences. He analyses the stories of four student teachers in their first year as primary teachers. As in many studies, the early experiences of teaching, especially of being responsible for ones' own class, were cited as major sources of learning how to be a teacher. The four teachers frequently referred to their experiences of teaching, but none illustrated how their early life outside school could have coloured their teaching.

A recent UNESCO Report (UNESCO, 2005) Focusing Resources on Effective School Health also emphasises life skills. In addition to these, young people also need skills that will help them adapt to changes over a lifetime. They need skills in each of the four pillars of Education for All: learning to know, learning to do, learning to live together and with others, and learning to be. Individuals need cognitive, reflective self-management and social skills.

\section{Research questions and method}

In this study, student teachers evaluate the future of preschool and primary school children, specifically regarding the language development and communication in the year 2030. The following research questions were explored:

1. How important is it for student teachers that children in preschool and primary school in the year 2030:

a) can use language and communication, and

b) can work in groups and in their environment?

2. How will preschool and primary school teachers support language learning and communication in the year 2030?

3. How will children in preschool and primary school in the year 2030 take responsibility for their own (child-centred) learning?

The research method involved a questionnaire, and the data were gathered in October 2007 from 76 student teachers studying at the Department of Applied Science of Education at the University of Helsinki. Of the students, 52 were preschool student teachers and 24 primary school student teachers.

The questionnaire consisted of 70 questions and was created for this particular study. Its design was based on the authors' knowledge and work experience in language 
development, communication and teacher training (see Nurmilaakso, 2006). The questionnaire is divided into three subsections according the three research questions above. Questions 7 to 35 of the questionnaire relate to the first research question (questions 21 and 35 were open questions not covered in this study). Questions 36 to 53 of the questionnaire relate to the second research question ( 53 was an open question and it is not covered in this study). Questions 54 to 69 of the questionnaire relate to the third research question. This study focuses only on questions 54 to 55 . The last question was an open question, and answers to this question are not covered in this study.

Every year, 100 preschool student teachers and 110 primary school student teachers begin their studies at the University of Helsinki. The data for this study has been gathered from the third-year student teachers taking the course "Native language and literature" taught by the author. All of these students had taken at least one course in language development or learning to read and write. All 76 students attending this course answered the questionnaire. The variables were measured on an ordinal (Likert) scale that offered students five options ("very important", “important”, "I can't say/somewhat important”, "not so important" and "unimportant") for each answer. The data was analysed using SPSS (Tabachnick \& Fidell, 2001) statistical software, and the frequencies as well as the t-test were implemented for data statistical analysis.

\section{Results}

What should children learn in preschool and primary school in the year 2030?

The student teachers considered as "very important" or "important" $(72.0 \%)$, that children in the preschool are prepared for reading. Most of the student teachers $(64.0 \%)$ felt that in the preschool, children's awareness of the language matures. The student teachers believed that children's self-concept as readers should be positive $(94.7 \%)$ and that children should show enthusiasm for reading. The students thought that it was unimportant that children learn to read in preschool $(68.0 \%)$. Less than a half of the students $(45.3 \%)$ said that it would be good for children learn to read in preschool. And $86.7 \%$ of the student teachers believed that the most important responsibility of primary school is to teach children to read.

The results of t-tests between preschool and primary school student teachers results regarding the variables "In preschool children learn to behave in a group", "Children should learn to read in preschool" and "The sole duty of primary school is to teach children to read" showed no statistically significant difference $(\mathrm{p}<0.05$ and $\mathrm{p}=0.05)$ between the groups. These questions were selected for statistical analysis as for many preschool and primary school teachers in Finland these are issues of high importance. In Finland, the compulsory school age is seven. One half of preschool children can read before primary school. In Finland, the issue of whether the compulsory school age should be six, as it is in many European countries, has generated much discussion.

The student teachers also evaluated how important it is that children master language and communication (see Table 1). The majority of respondents thought that it is very important that child can use language in the learning situations to develop her/his own knowledge. Only $26.3 \%$ of students said that it is very important that child can use language to achieve his/her goals. Majority of students $(61.8 \%)$ emphasised that it is very important that child can use language for practical application of learned things. 
One's native language is the most important language. Though, it is also important that in future Finns will be able to use diverse languages and have a good vocabulary since Finnish is not common language. However, the student teachers $(92.0 \%)$ felt that it will not be so important for children in 2030 to speak many languages.

Table 1. Evaluation of the importance of children's mastering of language and communication

\begin{tabular}{lcccccc}
\hline \multicolumn{1}{c}{$\begin{array}{c}\text { Items regarding } \\
\text { mastering language } \\
\text { and communication }\end{array}$} & $\begin{array}{c}\text { Very } \\
\text { important }\end{array}$ & Important & $\begin{array}{c}\text { I can't say/ } \\
\text { somewhat } \\
\text { important }\end{array}$ & $\begin{array}{c}\text { Not so } \\
\text { important }\end{array}$ & $\begin{array}{c}\text { Unim- } \\
\text { portant }\end{array}$ & N \\
\hline $\begin{array}{l}\text { Children's language is } \\
\text { multifaceted, ranging from } \\
\text { rhyming to talking nonsense }\end{array}$ & $21(28.0 \%)$ & $36(48.0)$ & $15(20.0 \%)$ & $3(4.00 \%)$ & $0(0.00 \%)$ & 75 \\
\hline $\begin{array}{l}\text { Children's vocabulary } \\
\text { includes many synonyms }\end{array}$ & $7(9.30 \%)$ & $23(30.7 \%)$ & $34(45.3 \%)$ & $8(10.7 \%)$ & $3(4.0 \%)$ & 76 \\
\hline $\begin{array}{l}\text { Children can speak several } \\
\text { languages }\end{array}$ & $0(0.00 \%)$ & $0(0.00 \%)$ & $6(8.0 \%)$ & $35(46.7 \%)$ & $34(45.3 \%)$ & 75 \\
\hline $\begin{array}{l}\text { Children's language includes } \\
\text { loanwords from other } \\
\text { languages, such as English }\end{array}$ & $0(0.00 \%)$ & $2(2.70 \%)$ & $6(8.00 \%)$ & $31(41.3 \%)$ & $36(48.0 \%)$ & 75 \\
\hline $\begin{array}{l}\text { Children speak their own } \\
\text { dialect }\end{array}$ & $13(17.6 \%)$ & $23(31.1 \%)$ & $22(29.7 \%)$ & $16(21.6 \%)$ & $0(0.00 \%)$ & 74 \\
\hline
\end{tabular}

The student teachers also responded to questions on how a child can work in groups and in his/her environment. More than half of students $(55.3 \%)$ thought that it is very important that a child can use language to explain his/her wishes and needs to an adult. Even more students $(78.9 \%)$ said that is very important or important that a child can use language in learning situations to develop group knowledge. Many children who experience difficulties with language development and later with learning to read and write also experience difficulties in using language with other children. Many times a child can manage just because it is easier to speak to an adult than to one's peers.

The students said that it is very important $(81.3 \%)$ that children in preschool learn to work in a group and to use language. It modifies the children's behaviour in their environment. Whether in groups or in their environment, children must use language and communication. The student teachers $(57.9 \%)$ said that it is very important that child can use language to adapt to his/her environment. This means, for example, that child can ask permission from his/her peers to play together. If a child cannot ask it, he/ she may feel as outsider already very early in childhood. Besides, the students $(64.5 \%)$ considered it very important that a child enjoy communication with other children, fewer student teachers $(52.0 \%)$ thought that it is very important that child enjoy communicating with adults. It also was perceived as very important that children enjoy their learning and playing.

\section{How will preschool and primary school teachers support language learning and communication in the year 2030 ?}

The duty of teachers in preschool and primary school is to support language development. They can support children's language learning and communication with the actions reflected in Table 2. 
Table 2. Evaluation of the role of children's productions for language learning and communication

\begin{tabular}{|c|c|c|c|c|c|}
\hline Children's productions & $\begin{array}{l}\text { Very } \\
\text { important }\end{array}$ & Important & $\begin{array}{l}\text { I can't say/ } \\
\text { somewhat } \\
\text { important }\end{array}$ & $\begin{array}{l}\text { Not so } \\
\text { important }\end{array}$ & $\begin{array}{l}\text { Unim- } \\
\text { portant }\end{array}$ \\
\hline $\begin{array}{l}\text { Children tell stories while } \\
\text { an adult writes them down }\end{array}$ & $49(64.5 \%)$ & $26(34.2 \%)$ & $1(1.30 \%)$ & $0(0.00 \%)$ & $0(0.00 \%)$ \\
\hline $\begin{array}{l}\text { Children have ABC-books } \\
\text { in the first class }\end{array}$ & $34(44.7 \%)$ & $29(38.2 \%)$ & $9(11.8 \%)$ & $4(5.30 \%)$ & $0(0.00 \%)$ \\
\hline $\begin{array}{l}\text { Children's scribbles have } \\
\text { been discussed }\end{array}$ & $32(42.1 \%)$ & $32(42.1 \%)$ & $10(13.2 \%)$ & $1(1.30 \%)$ & $1(1.30 \%)$ \\
\hline $\begin{array}{l}\text { Children's drawings with } \\
\text { writings are exhibited and } \\
\text { discussed }\end{array}$ & $40(52.6 \%)$ & $25(32.5 \%)$ & $9(11.8 \%)$ & $2(2.60 \%)$ & $0(0.00 \%)$ \\
\hline $\begin{array}{l}\text { Children's writings and } \\
\text { drawings have been } \\
\text { compiled in an annual } \\
\text { portfolio }\end{array}$ & $27(35.5 \%)$ & $25(32.9 \%)$ & $12(15.8 \%)$ & $10(13.2 \%)$ & $2(2.60 \%)$ \\
\hline $\begin{array}{l}\text { Children's own writings } \\
\text { are exhibited in the } \\
\text { classroom }\end{array}$ & $34(44.7 \%)$ & $23(30.3 \%)$ & $15(19.7 \%)$ & $3(3.90 \%)$ & $1(1.30 \%)$ \\
\hline
\end{tabular}

Method of children telling a story while an adult writes it down, is a very successful in Finland. The answers suggest that children should see many writings around them and that their drawings, together with writings should be exhibited in the classroom and discussed.

Teachers can support language learning and communication in many other ways. Nowadays children work and communicate through the Internet and computers. The student teachers were asked how much these actions encourage language learning and communication. The students $(82.9 \%)$ said that children are interested in language (e.g., logos in newspapers). According to student teachers, it is not so important that teachers support language learning and communication with multimedia. Only a few students said that teachers can promote language learning in such a way that children use computers and mobile phones very much in preschool and primary school.

\section{How will children in preschool and primary school in the year 2030 take responsibility for their own (child-centred) learning?}

The child-centred philosophy has grown in Finland during the past few centuries. In the real world, this means that a child's actions become more and more independent, even in preschool. According to student teachers, these actions promote language learning and communication. Children tell their own stories $(89.5 \%)$ and frequently $(62.7 \%)$ draft their own written productions. Children often visit the library as well $(67.1 \%)$ and this number includes library visits with parents. Children in preschool and primary schools $(42.1 \%$ very often) use books when trained for language and reading. The student teachers said that children $(1.30 \%)$ are not so interested in playwriting and reading, which require children to imagine themselves writing and reading even though they really cannot: one example might be when a child (who cannot read) pretends to 
teach his/her teddy bear to read (Nurmilaakso, 2006). And children (6.60\%) seldom scribble on their drawings.

According to the student teachers, it is important to consider the children's personal goals when planning activities in preschool. Every child's personal learning path must be clarified in preschool $(68.4 \%$ completely agreed or mostly agreed). Children in preschool and primary school in the year 2030 should take responsibility for their own (child-centred) learning.

However, all student teachers admitted that planning such activities - or adult's planning - is not so important. The majority $(81.6 \%)$ said that one's learning difficulties must be handled already in preschool and that co-operation between preschool and primary school education should be regular (76.3\% completely agreed).

One must begin with every child's personal motivation and personal learning path, and co-operation between preschool and primary school education should be regular. The student teachers thought that it is important for every child to receive detailed feedback on his/her own work (93.4\% completely agreed). The students thought that it would be good for children to realistically evaluate their own work $(42.1 \%$ mostly agreed). The student teachers (75.0\% completely agreed) hoped that children would enjoy their learning.

\section{Discussion}

The results of this study confirm the conception that preschool and primary school teachers and student teachers think very traditionally. For example, many felt that it will not be so important for children in 2030 to speak many languages. This finding is very surprising because knowing other languages is a lifeline for Finns, since so few Finnish speakers exist outside of Finland. According to Gardner (1999), the school and the church are such uncommon institutions in that they have changed little during the past hundred years, even as the society around them has changed tremendously and moves more quickly. The results of this study support these opinions.

Winch, Johnston, Holliday, Ljungdahl, and March (2001) suggest that a modern child, already at very young age, encounters an environment full of texts. Researchers advise that adults and day care centres provide the opportunity for children to be open to texts, and adults must help children practise reading and writing to prepare for school. These early encounters with learning environment are unexpectedly valuable, especially if the children begin to understand what it means learning to read and to write, and how to use these skills in the social realm in which they live (see also Jalongo, Dragich, Conrad, \& Zhang, 2002; Whitehead, 2003; Nurmilaakso, 2003). In this study, the student teachers admitted that it is very important that child can use his/her native language fluently. Nowadays, a child is born into a society which surrounds him/her with scribbles, brochures, pictures and so on. The environment is full of different kinds of writing. When the child is very young, he/she can already begin to recognise different signs. A two- or three-year-old child knows where a shop is when he/she sees its name or logo. In this way children learn to read their environment. The world has changed and so has the conception of how children learn to learn.

Tella (2003) says that teachers' resistance to multimedia such as computers and mobiles in education is worrisome because teachers at all levels and in all sectors are key in shaping the knowledge society. Possible reasons for teachers' low motivation to 
use technology in their teaching could stem from a fear of seemingly obscure and dauntingly complex concepts such as e-learning which, according to Tella, is a kind of cliché. In addition, technologies have been overemphasised, especially during the 1990s, because of the popularity of developing and testing e-learning platforms.

On the other hand, the overemphasised role of the constructivist approach may also be an obstacle. Finally, according to Karevaara and Thuss (2002), few teachers really understand what "technologies" mean, particularly as the distinction between hardware and software technologies fades due to the multi-layered nature of programming. Chen and Chang (2006) are of the same opinion. Although computer technology has been recognised for its great potential to enhance teaching and learning, the results of their recent studies indicate that many early childhood teachers are not ready to integrate computers into the classroom.

Perhaps the student teachers believe that preschool and primary school children are too young to need the latest technology. According to Reunamo and Nurmilaakso (2006), however, young children need secure and sufficiently permanent surroundings for balanced development. Long-term relations and good daily routines are the foundations of a healthy childhood. Perhaps it is because young children themselves change so quickly in their early years that they need relatively stable conditions for their upbringing. Our world changes faster every day. As a result, children need peace and love to adapt better to markers of change, such as computers, because children must experience such changes early in their childhood.

Nevertheless, we must always remember the culture in which we live when we speak of the future. Pedagogical views are deeply rooted in the functions of our basic understanding of early childhood learning. These roles also call for a new interpretation of children's use and learning of language. Language is not just a means for communication or understanding; it is also an important ingredient in cultural production. Learning and teaching are interwoven and they cannot be considered separately. In the future, the teacher's task will be to understand the link between different types of learning and between different pedagogies and to choose which is the most appropriate for a given situation (Reunamo \& Nurmilaakso, 2007).

\section{References:}

Barnes, A. (2008). Future-wishing, magical fantasies, yet being "real": Snapshots of student teachers perceptions during their initial training. Teacher Development: An International Journal of Teachers' Professional Development, 12(1), 3-13.

Chen, J-Q., \& Chang, C. (2006). Using computers in early childhood classrooms. Teachers' attitudes, skills and practices. Journal of Early Childhood Research, 4(2), 169-188.

Core Curriculum for Pre-school Education in Finland. (2000). National Board of Education. Helsinki: Yliopistopaino/University Press.

Core Curriculum for Basic Education. (2004). National Board of Education. Helsinki: Board of Education.

Gardner, H. (1999). Disciplined mind. What all students should understand. New York: Simon \& Schuster.

Hujala, E. (2002). The curriculum for early learning in the context of society. International Journal of Early Years Education, 10(2), 95-104. 
Jalongo, M. R., Dragich, D., Conrad, N. K., \& Zhang, A. (2002). Using wordless picture books to support emergent literacy. Early Childhood Education Journal, 29(3), 167-177.

Karevaara, K., \& Thuss, F. (2002). A future of e-learning research? Introduction to some Finnish and Dutch perceptions about integrated or blended learning. In F. Buchberger, D. Baur, \& K. Berghammer (Eds.), @-learning in higher education (pp. 59-67). Linz: Universitaetsverlag Trauner.

Korkeamäki, R.-L. (2006). Finnish teacher education: Preparing teacher students for early literacy education. In R. Jakku-Sihvonen \& H. Niemi (Eds.), Research-based teacher education - Reflections by Finnish teacher educators (pp. 153-162). Finnish Educational Research Association. Turku: Painosalama.

Meri, M. (2004). Vanhassa vara parempi. Käsiteanalyysia kvantitatiivisin keinoin [It is better to trust the tried and true. Using quantitative methods for concept analysis]. In P. Kansanen \& K. Uusikylä (Eds.), Opetuksen tutkimuksen monet menetelmät [The many methods of teaching research] (pp. 99-112). Jyväskylä: PS-kustannus.

Niikko, A. (2002). Lastentarhanopettajat esiopetuksen toteuttajina [Preschool education in the vicinity of the castle]. In A. Niikko (Ed.), Esiopetusta linnan liepeillä [Kindergarten teachers as initiators in preschool education] (pp. 140-147). University of Joensuu, Department of Teacher Education, Savonlinna.

Nurmilaakso, M. (2003). The significance of cooperation with parents for stimulation of language development in the day-care-centre. Paper presented at the 13th European Conference on Quality in Early Childhood Education, September 3-6, Glasgow, Scotland.

Nurmilaakso, M. (2006). Lukemisen alkeita päiväkodissa - Lastentarhanopettaja ja alkava kuusivuotias lukija [Early literacy development in day-care-centre]. Unpublished doctoral dissertation. University of Helsinki, Helsinki, Finland.

Ojala, M. (2004). Helsinki study: Learning in the modern preschool settings for sixyear-old children. Journal of Teacher Education and Training, 4, 45-56.

Ojala, M., Siekkinen, M., \& Wright, J. (1996). Developing a multimedia vision of children's learning challenges from theory to everyday practise. Paper presented at the Conference Matkalla tietoybteiskuntaan. Interaktivinen teknologia koulutuksessa [A travel to multimedia society. The interactive theory in training]. April 19-20, Hämeenlinna, Aulanko, Finland.

Reunamo, J., \& Nurmilaakso, M. (2006). Language objectives in the Finnish preschool curriculum. In A. Pipere (Ed.), Education and sustainable development: First steps toward changes (vol.1, pp.188-201). Daugavpils University: Saule.

Reunamo, J., \& Nurmilaakso, M. (2007). Vygotsky and language development. European Early Childhood Research Journal, 15(3), 313-327.

Smith, R. G. (2007). Developing professional identities and knowledge: Becoming primary teachers. Teachers and Teaching: Theory and Practice, 13(4), 377-397.

Tabachnick, B. G., \& Fidell, L. (2001). Using multivariate statistics (4nd ed.). United States of America.

Tella, S. (2003). M-learning-cybertextuality or mobile nomadism? In H. Kynäsahti \& P. O. Seppälä (Eds.), Professional mobile learning (pp. 7-21). Helsinki: IT Press.

UNESCO. (2005). Focusing resources on effective school health. Retrieved May 16, 2005, from http://portal.unesco.org/education/en/ev.phpURL 
Whitehead, M. (2003). Supporting language and literacy development in the early years (2nd ed.). Guildford and King's Lynn: Biddles Ltd.

Winch, G., Johnston, R. R., Holliday, M., Ljungdahl, L., \& March, P. (2001). Literacy, reading, writing, and children's literature. Australia: Oxford University Press.

Vygotsky, L. (1978). Mind and society. Cambridge MA: Harvard University Press.

Välijärvi, J., Linnakylä, P., Kupari, P., Reinikainen, P., Malin, A., \& Puhakka, E. (2002). Suomen tulevaisuuden osaajat. Toinen painos [Experts of Finlands' future]. Jyväskylä: Er-paino $\mathrm{Oy}$.

Yoon, K. (2006). Education for the future as perceived by professors, cooperating teachers, and student teachers in Korea. In A. Pipere (Ed.), Education and sustainable development: First steps toward changes (vol. 1, pp. 338-351). Daugavpils University: Saule.

\section{Correspondence:}

Marja Nurmilaakso, PhD, Department of Applied Sciences of Education, Research Centre for Early Childhood and Elementary Education, P.O. Box 9 (Siltavuorenpenger 20 M), FIN - 00014, University of Helsinki, Finland. Email: marja.nurmilaakso@helsinki.fi

Received 15 December, 2008; revised version received 15 April, 2009 